\title{
Negen kernelementen die volgens betrokken professionals bijdragen aan het succes van Zwolle Gezonde Stad
}

\author{
Een integrale, lokale aanpak om gezondheidsverschillen te verkleinen
}

\author{
Lisa Wilderink · Ingrid Bakker · Albertine J. Schuit · Jacob C. Seidell · Carry M. Renders
}

Geaccepteerd op: 16 februari 2021 / Published online: 12 maart 2021

(C) The Author(s) 2021

\begin{abstract}
Samenvatting De aanpak Zwolle Gezonde Stad heeft succesvol gezondheidsverschillen teruggedrongen. Het doel van dit onderzoek is om te achterhalen wat volgens verschillende betrokken professionals de kernelementen van Zwolle Gezonde Stad zijn. Daartoe is een kwalitatief onderzoek uitgevoerd. Semigestructureerde interviews zijn gehouden met 29 professionals van betrokken organisaties. Na analyse van de interviews is met zeven respondenten een toetsend focusgroepgesprek gehouden. Negen kernelementen van de aanpak van Zwolle Gezonde Stad zijn geïdentificeerd: 1) samenwerken met een gevarieerde groep lokale organisaties, 2) draagvlak voor de aanpak op strategisch, tactisch en operationeel niveau, 3) communicatie en coördinatie, 4) samenwerking met private organisaties, 5) samenwerking met bewoners, 6) profileren van de aanpak, 7) meebewegen met en gebruikmaken van mogelijkheden en kansen, 8) borging van de aanpak in beleid en de processen, en 9) doorlopend monitoren van proces en effect. Deze negen kernelementen hebben volgens de betrokken
\end{abstract}

Dit is een bewerking van Wilderink L, Bakker I, Schuit AJ, et al. Key elements of a successful integrated community-based approach aimed at reducing socioeconomic health inequalities in the Netherlands: a qualitative study. PloS one 2020;15 (10):e0240757.

L. Wilderink $(\square) \cdot$ J. C. Seidell $\cdot$ C. M. Renders Department of Health Sciences, Faculty of Sciences, Public Health research institute, Vrije Universiteit Amsterdam, Amsterdam, Nederland

L.Wilderink@vu.nl

L. Wilderink · I. Bakker · C. M. Renders

Lectoraat Gezonde Samenleving, Hogeschool Windesheim, Zwolle, Nederland

A. J. Schuit

School of Social and Behavioral Sciences, Tilburg University, Tilburg, Nederland professionals bijgedragen aan het succes van Zwolle Gezonde Stad. Deze inzichten zijn belangrijk voor de doorontwikkeling van de aanpak Zwolle Gezonde Stad en kunnen andere lokale integrale benaderingen inspireren.

Trefwoorden sociaaleconomische gezondheidsverschillen · kernelementen · integrale aanpak $\cdot$ kwalitatief onderzoek

Nine key elements that contribute to the success of the Zwolle Healthy City

An integrated, local approach to reduce health inequalities

Abstract Since 2010, the Zwolle Healthy City approach has been implemented in Zwolle and is successful in reducing health inequalities. However, the key elements are not clear. The current study aimed to identify key elements of this successful local community-based approach, according to the perspectives of stakeholders. Semi-structured interviews were carried out with 29 professionals at the strategic $(n=4)$, tactical $(n=17)$ and operational level $(n=8)$. Data were analyzed using the thematic analysis approach. We identified nine key elements that contributed to the success of the approach: 1) collaboration between a variety of local organizations, 2) support for the approach on the strategic, tactical and operational level, 3) communication and coordination, 4) collaboration with private organizations, 5) collaboration with citizens, 6) profiling the approach, 7) moving along with and taking advantage of opportunities, 8) embeddedness in organizations' policies and processes, and 9) continuous monitoring and evaluating goals and processes. According to stakeholders, these nine key elements contributed to the success of the Zwolle Healthy City approach. These insights are important 
to further strengthen the Zwolle Healthy City approach and inspire other local integrated communitybased approaches aimed at reducing socioeconomic health inequalities.

Keywords Socioeconomic health inequalities • Community-based approach · Key elements . Qualitative research

\section{Inleiding}

Mensen met een lage sociaaleconomische positie (SEP) laten gemiddeld meer ongezond eet- en beweeggedrag zien dan mensen met een hoge SEP [1]. Dit ongezonde gedrag draagt bij aan een slechter ervaren gezondheid en een hogere prevalentie van overgewicht en andere niet-overdraagbare ziekten. Daardoor hebben mensen met een lage SEP gemiddeld een lagere (gezonde) levensverwachting dan mensen met een hogere SEP [2, 3].

Deze sociaaleconomische gezondheidsverschillen (SEGV) worden veroorzaakt door verschillende determinanten van ongezond gedrag op het individuele niveau, zoals stress, minder geloof in eigen kunnen voor gedragsverandering, gebrek aan kennis over de gezonde keuze en slechtere gezondheidsvaardigheden [4-7]. Ook biedt de sociale en fysieke leefomgeving in lage SEP-wijken minder mogelijkheden voor gezond gedrag [8-11]. Mensen met een lage SEP wonen bijvoorbeeld vaker in wijken met minder openbaar groen waarin ze kunnen bewegen, meer zichtbare marketing van ongezonde producten en gemiddeld meer fastfoodrestaurants [12, 13]. Sociale kenmerken van de wijk, zoals ervaren sociale veiligheid en sociale cohesie, hebben ook een invloed op beweeggedrag [14]. Door deze complexe combinatie van factoren die bijdragen aan SEGV vraagt het verkleinen van deze verschillen om een integrale aanpak op verschillende niveaus (individu, wijk, samenleving), die zich richt op factoren in zowel de sociale als de fysieke leefomgeving $[15,16]$.

Ook in Nederland vormen SEGV een uitdaging voor beleid en maatschappij [17]. Nederlandse gemeenten worden door de nationale overheid aangemoedigd om de Jongeren Op Gezond Gewicht (JOGG)-aanpak te implementeren. Deze integrale wijkgerichte benadering stimuleert gezond gedrag in een gezonde omgeving en zet in op het stimuleren van gezond gewicht bij kinderen. De JOGG-aanpak kan SEGV terugdringen door vooral in te zetten op het stimuleren van gezond gedrag in achterstandswijken.

In 2010 werd Zwolle de eerste JOGG-gemeente. Deze lokale aanpak, genaamd Zwolle Gezonde Stad, is in de eerste periode tot 2014 succesvol gebleken in het verminderen van overgewicht bij kinderen in de lage SEP-focuswijken meer dan in de andere wijken. Daarmee heeft de aanpak een bijdrage geleverd aan het verkleinen van gezondheidsverschillen. In de twee focuswijken waar bewoners gemiddeld de laagste sociaaleconomische status hebben, nam het percentage kinderen met overgewicht in die eerste paar jaar meer af dan in andere wijken in Zwolle [18]. Bovendien zijn ook resultaten op procesniveau behaald: door Zwolle Gezonde Stad is publiek-private samenwerking ontstaan, is samenwerking tussen beleid, praktijk, onderzoek en onderwijs geborgd, en is de ketenaanpak van overgewicht en obesitas in Zwolle versterkt. Vandaag de dag voert meer dan een derde van alle Nederlandse gemeenten de JOGG-aanpak uit.

Evaluaties van Zwolle Gezonde Stad en ook JOGGinitiatieven in andere gemeenten laten in veel gevallen veranderingen zien in (on)gezond gedrag van kinderen. In verschillende JOGG-gemeenten zijn de percentages overgewicht afgenomen en in Zwolle werden SEGV verkleind [18, 19]. De kernelementen, de cruciale 'sleutelfactoren', van deze aanpak zijn echter niet bekend.

Het doel van het huidige onderzoek is te achterhalen wat volgens verschillende betrokken professionals de kernelementen van de aanpak van Zwolle Gezonde Stad zijn. We doen dit door te reflecteren op de implementatie van de aanpak in de eerste acht jaar (2010-2018). Deze inzichten leveren aangrijpingspunten op voor verbetering van de aanpak Zwolle Gezonde Stad. Bovendien kunnen andere vergelijkbare benaderingen er inspiratie uit putten voor hun specifieke lokale context.

\section{Methode}

\section{Onderzoekontwerp}

Om de kernelementen van de aanpak 'Zwolle Gezonde Stad' te achterhalen is een kwalitatief onderzoek uitgevoerd. Er zijn semigestructureerde interviews over de implementatie en uitvoering van de aanpak gehouden met betrokken professionals van verschillende organisaties: gemeente, GGD, hogeschool, twee welzijnsorganisaties, een thuiszorgorganisatie en de sportserviceorganisatie.

\section{Setting}

De aanpak van Zwolle Gezonde Stad is gericht op het stimuleren van gezond gedrag door in te zetten op een gezonde leefstijl, een gezonde fysieke en sociale omgeving en gezonde zorg in lage SEP-gebieden. Daarmee beoogt deze SEGV te verkleinen (zie fig. 1 voor het logisch model). In 2010 is gestart met de implementatie, geïnspireerd op de Franse EPODE-benadering [20]. In Nederland heet de aanpak sindsdien JOGG. In Zwolle ging het in de eerste jaren om het bevorderen van gezonde voeding en voldoende bewegen bij kinderen van nul tot negentien jaar. Omdat uit de evaluatie in 2014 bleek dat de aanpak van Zwolle Gezonde Stad succesvol is, werd door het netwerk van betrokken organisaties besloten de aanpak breder in te zetten. Naast jongeren behoren nu ook thuiswonende 


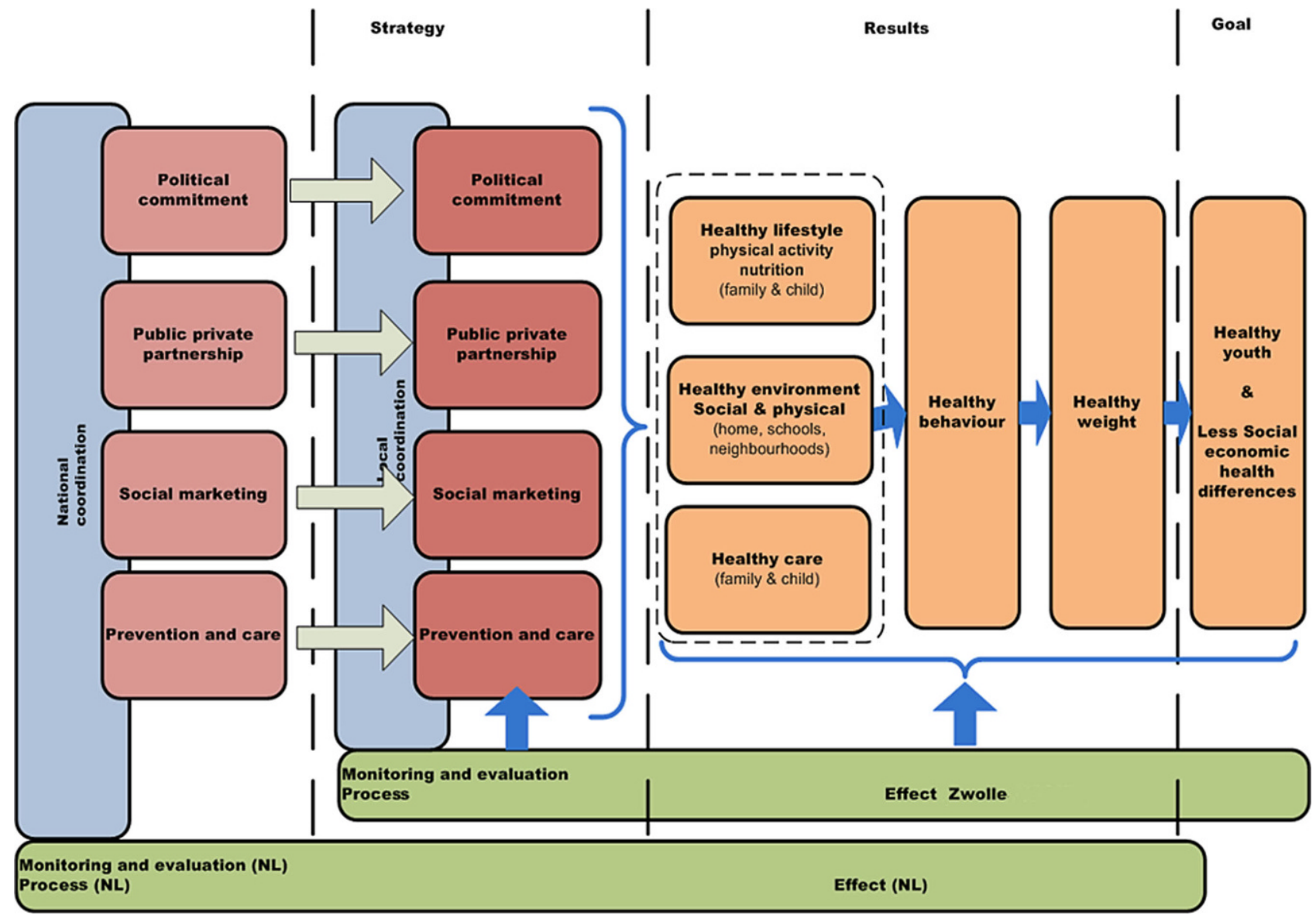

Figuur 1 Logisch model van de aanpak Zwolle Gezonde Stad

ouderen tot de doelgroep, en is er sindsdien aandacht voor alcoholpreventie [21]. Aan de twee wijken met de meeste gezondheidsachterstanden zijn drie geografische gebieden toegevoegd.

\section{Onderzoekspopulatie}

Er zijn 29 professionals geïnterviewd die bij de aanpak betrokken zijn (geweest) op strategisch (wethouders, $n=4$ ), tactisch (programmagroepsleden: managers, beleidsadviseur en (associate) lectoren, $n=17$ ) en operationeel niveau (wijkprofessionals: onder andere jongerenwerkers en buurtsportcoaches, $n=8$ ). (tab. 1).

\section{Datacollectie en analyse}

De respondenten zijn geïnterviewd over hun ervaringen met de aanpak van Zwolle Gezonde Stad tijdens de periode 2010-2018. De duur van de interviews varieerde van 49 tot 92 minuten. De laatste vier interviews leverden niet veel nieuwe informatie op, wat betekent dat datasaturatie was bereikt. De gebruikte interview guide is gebaseerd op het logisch model van de aanpak Zwolle Gezonde Stad (zie fig. 1), literatuur over dit soort benaderingen en eerdere gesprekken met betrokken professionals in 2013 (deels dezelfde professi- onals). De interview guide bestond uit open vragen en vervolgvragen over de volgende thema's: lokale structuur en coördinatie, draagvlak, interventies en activiteiten, verbinden van preventie en zorg, monitoring en evaluatie, samenwerking en participatie.

De interviews zijn opgenomen en letterlijk getranscribeerd. MAXQDA is gebruikt om de data te analyseren. De interviews zijn systematisch geanalyseerd met een thematische contentanalyse om terugkerende thema's te achterhalen.

$\mathrm{Na}$ analyse van de 29 semigestructureerde interviews is een toetsend focusgroepgesprek gehouden met zeven respondenten (vier programmagroepsleden en drie wijkprofessionals), om de voorlopige uitkomsten te verifiëren en waar nodig nader te laten toelichten. Naar aanleiding van het focusgroepgesprek zijn enkele uitkomsten licht aangepast wat betreft taal en structuur.

\section{Resultaten}

Op basis van het uitgevoerde onderzoek zijn negen kernelementen van de aanpak van Zwolle Gezonde Stad bepaald. De kernelementen en onderliggende subthema's zijn hieronder beschreven. Een overzicht is te vinden in tab. 2 . 
Tabel 1 Overzicht van betrokken organisaties en het aantal respondenten dat werkt voor de betreffende organisatie $(n=29)$

\begin{tabular}{|l|l|c|l|c|} 
& Strategisch & Tactisch & Operationeel & Totaal \\
\hline Gemeente & 4 & 2 & 0 & 6 \\
\hline Hogeschool & 0 & 4 & 0 & 4 \\
\hline GGD & 0 & 2 & 0 & 2 \\
\hline Sportserviceorganisatie & 0 & 2 & 3 & 5 \\
\hline Welzijnsorganisatie & 0 & 4 & 5 & 9 \\
\hline Thuiszorgorganisatie & 0 & 3 & 0 & 3 \\
\hline Totaal & 4 & 17 & 8 & 29 \\
\hline
\end{tabular}

\section{Samenwerken met een gevarieerde groep lokale organisaties}

Volgens de respondenten is het belangrijk om samen te werken met een gevarieerde, intersectorale groep van organisaties, die ondanks verschillen in missies, taken en werkwijzen, een gemeenschappelijk doel hebben. De organisaties vertegenwoordigd in de Zwolle Gezonde Stad programmagroep zijn de gemeente, GGD IJsselland, thuiszorgorganisatie Icare, SportService Zwolle, Travers Welzijn, Hogeschool Windesheim en WijZ welzijn. Het werkelijke netwerk van organisaties waarmee wordt samengewerkt is nog breder.

'Een coalition of the willing is het eigenlijk. Mensen die willen die kunnen aansluiten en die kunnen veel betekenen. De organisaties zelf die moeten het belang inzien. En zolang je dat inziet, doe je mee en zet je je daarvoor in. Eigenlijk zou je een soort heel brede coalitie willen hebben van partijen die ertoe doen.' (programmagroepslid)

Wat volgens de respondenten goed werkt is dat het netwerk onafhankelijk en niet-hiërarchisch functioneert - het besluit over de eigen agenda. Deze onafhankelijkheid versterkt een gevoel van autonomie. Enkele respondenten geven echter aan dat er sprake is van schijngelijkwaardigheid doordat de gemeente voor publieke partners binnen het netwerk een dubbele rol heeft: als gelijke netwerkpartner in Zwolle Gezonde Stad, maar ook als financierder. Dit kan zorgen voor onduidelijkheid over rollen, verwachtingen en onafhankelijkheid, wat de samenwerking niet altijd ten goede komt. De niet-hiërarchische structuur kan ook verlammend werken doordat er soms onduidelijkheid is over taken en verantwoordelijkheden.

Naast de samenwerking op het tactische niveau in een netwerk (via de programmagroep) is het volgens de respondenten ook belangrijk dat verschillende organisaties op het operationele (wijk)niveau met elkaar samenwerken en van elkaars expertise gebruikmaken.
Tabel 2 Overzicht van de kernelementen met onderliggende subthema's

\begin{tabular}{|c|c|}
\hline Kernelement & Subthema \\
\hline \multirow{4}{*}{$\begin{array}{l}\text { Samenwerken met } \\
\text { een gevarieerde } \\
\text { groep lokale organi- } \\
\text { saties }\end{array}$} & Coalition of the willing \\
\hline & $\begin{array}{l}\text { Gemeenschappelijk doel, ondanks verschillende } \\
\text { missies, taken en werkwijzen }\end{array}$ \\
\hline & Afstemmen van uitvoering en expertise delen \\
\hline & $\begin{array}{l}\text { Tevens samenwerken op het operationele } \\
\text { (wijk)niveau }\end{array}$ \\
\hline \multirow{3}{*}{$\begin{array}{l}\text { Draagvlak op ieder } \\
\text { niveau: strategisch, } \\
\text { tactisch en operatio- } \\
\text { neel }\end{array}$} & Breed politiek-bestuurlijk draagvlak \\
\hline & Win-winprincipe \\
\hline & Communiceren met uitvoerende professionals \\
\hline \multirow{3}{*}{$\begin{array}{l}\text { Communicatie en } \\
\text { coördinatie }\end{array}$} & Netwerkcoördinator (programmamanager) \\
\hline & Communicatie en afstemming binnen organisaties \\
\hline & Leiderschap binnen organisaties (interne coördinator \\
\hline \multirow{4}{*}{$\begin{array}{l}\text { Samenwerken met } \\
\text { private organisaties }\end{array}$} & (Financiële) middelen en kennis \\
\hline & Daadkracht \\
\hline & Private organisaties voor een specifiek doel vragen \\
\hline & Rol open laten \\
\hline \multirow{3}{*}{$\begin{array}{l}\text { Samenwerken met } \\
\text { bewoners }\end{array}$} & In kleine stappen en niet te lang \\
\hline & Vanaf het begin \\
\hline & Input snel omzetten in actie \\
\hline \multirow{3}{*}{$\begin{array}{l}\text { Profileren van de } \\
\text { aanpak }\end{array}$} & Onder de aandacht brengen bij organisaties \\
\hline & Succesverhalen koppelen aan de aanpak \\
\hline & Minder van belang voor bewoners \\
\hline \multirow{3}{*}{$\begin{array}{l}\text { Meebewegen met en } \\
\text { gebruikmaken van } \\
\text { mogelijkheden en } \\
\text { kansen }\end{array}$} & Aansluiten bij 'dat wat er al is' \\
\hline & Aansluiten bij reguliere werkprocessen \\
\hline & Aansluiten bij nationale kansen \\
\hline \multirow{2}{*}{$\begin{array}{l}\text { Borgen van aanpak in } \\
\text { beleid en processen } \\
\text { van organisaties }\end{array}$} & Borging in beleid en uitvoering \\
\hline & Overgang van programma naar beweging \\
\hline \multirow{3}{*}{$\begin{array}{l}\text { Doorlopend monito- } \\
\text { ren van proces en } \\
\text { effect; acties verbin- } \\
\text { den aan bevindingen }\end{array}$} & Effect meten en monitoren \\
\hline & Proces monitoren en daar conclusies uit trekken \\
\hline & Hogeschool betrokken \\
\hline
\end{tabular}

\section{Draagvlak op elk niveau: strategisch, tactisch en operationeel}

De respondenten geven aan dat binnen de betrokken organisaties op strategisch, tactisch en operationeel niveau draagvlak nodig is. Bij de gemeente moet er op het strategische niveau breed politiek-bestuurlijk draagvlak zijn, zodat samenwerking tussen verschillende portefeuilles mogelijk is. Bij de aanpak van Zwolle Gezonde Stad was niet alleen de wethouder Volksgezondheid betrokken, maar ook wethouders met bijvoorbeeld de portefeuilles Jeugd, Onderwijs, Sport, Ruimtelijke ordening en Sociaal domein.

'Dit kan nooit alleen iets van de wethouder Volksgezondheid zijn. Als we het doen, moeten we er als het hele college achter staan, want dit gaat namelijk ook over infrastructuur. Kunnen kinderen veilig naar school fietsen? Het gaat over speelgelegenheid in parken, dus dan gaat het over de openbare ruimte. Het gaat over veiligheid op straat, 
kun je veilig buiten zijn, wandelen, sporten. Ging over eigenlijk alle portefeuilles.' (wethouder)

Draagvlak op strategisch niveau bij de andere betrokken organisaties biedt mogelijkheden voor samenwerking en is belangrijk voor het faciliteren van middelen, uren en ondersteuning. Op het tactische niveau zijn draagvlak en gevoel van eigenaarschap belangrijk bij de betrokken organisaties in de programmagroep, zodat werkzaamheden en activiteiten onderling goed worden afgestemd. Op het uitvoerende niveau is draagvlak nodig onder wijkprofessionals om de activiteiten uit te voeren en doelgroepen te bereiken.

Om dit draagvlak te creëren en te behouden is het belangrijk dat er sprake is van een win-winprincipe: niet alleen moet de betrokkenheid van een organisatie voor Zwolle Gezonde Stad iets opleveren, maar ook voor de organisatie zelf. Denk bijvoorbeeld aan het onderhouden van contact met de wethouder, het uitwisselen van expertise of mogelijkheden om met andere organisaties samen te werken. Daarnaast wordt het draagvlak onder professionals vergroot als zij steun ervaren en uren krijgen van hun leidinggevende om aan de slag te gaan met het thema gezondheid. Daarbij moet er aandacht zijn voor helderheid over de doelen van de aanpak, de (meer)waarde van deelname aan het netwerk door de eigen organisatie en wat het betekent voor de werkzaamheden van de wijkprofessionals. Weten waarom ergens aandacht aan moet worden besteed, draagt positief bij aan het draagvlak onder professionals.

'Op een gegeven moment kwamen er wel geluiden vanuit de professionals die op wijkniveau werken, van, jullie zeggen wel van alles, maar wij weten eigenlijk helemaal niet wat dat betekent voor ons werk.' (programmagroepslid)

\section{Communicatie en coördinatie}

De respondenten geven aan dat er iemand moet zijn die met het netwerk van organisaties communiceert en activiteiten coördineert. In het geval van Zwolle Gezonde Stad is dit de taak van de programmamanager, die onder andere bijeenkomsten organiseert voor de programmagroep, de voortgang bewaakt en zo nodig de organisaties op hun taken en verantwoordelijkheden wijst. Volgens de respondenten is het belangrijk dat de programmamanager onafhankelijk is en los van het belang van de eigen organisatie kan opereren.

Ook is het binnen elke organisatie belangrijk dat de communicatie tussen het strategische, tactische en operationele niveau goed verloopt. Zo kunnen professionals de aanpak met elkaar afstemmen en wordt het draagvlak onder hen vergroot. Bovendien is het essentieel dat de aanpak binnen de betrokken organisaties goed gecoördineerd wordt. Een coördinator kan het thema gezondheidsbevordering agenderen bij collega's en integreren in de dagelijkse werkzaamheden van de wijkprofessionals.

\begin{abstract}
'Ik denk dat je gewoon echt iemand moet hebben die verantwoordelijk wordt voor dat thema Igezonde leefstijl], want anders wordt het gewoon weer een bijzaak (...). Die heeft dan ook als taak om de rest van de collega's te informeren en mee te nemen in dat thema.' (wijkprofessional)
\end{abstract}

\section{Samenwerken met private organisaties}

Alle respondenten geven aan dat samenwerking met private lokale organisaties van toegevoegde waarde kan zijn voor de aanpak. Dit kan de vorm aannemen van (financiële) middelen, kennis of daadkracht. Een respondent beschrijft het als 'een bonus, geen basis', omdat volgens hem duurzame samenwerking met een private organisaties niet voorkomt, maar deze wel bijzondere dingen kan opleveren, zoals realisatie van een interactieve Sutu-voetbalmuur in Zwolle. Verschillen in cultuur, taal of belangen kunnen de samenwerking bemoeilijken.

'Zij [private organisaties] zijn echt van de "Nou als we iets willen, dan huppakee, actie." Dus dat is een ander tempo.' (programmagroepslid)

Sommige respondenten geven aan dat het belangrijk is om private organisaties met een bepaalde expertise te vragen voor een specifiek doel in een project. Anderen ervaren dat private organisaties het minder prettig vinden wanneer hun beoogde rol door anderen bedacht is. Ze stellen dat het daarom beter is om private organisaties zelf te laten bepalen hoe zij aan de doelstellingen van de aanpak kunnen en willen bijdragen.

'Dus eigenlijk moet je het openlaten. Moet je gewoon zeggen van kijk, wij zijn Zwolle Gezonde Stad en dit is onze missie en dit zijn onze doelstellingen. Zouden jullie daarin willen helpen? En dan komen ze soms echt met briljante ideeën.' (programmagroepslid)

\section{Samenwerken met bewoners uit de aandachtswijken}

Veel respondenten vinden samenwerking met bewoners belangrijk, zodat de aanpak aansluit bij hun wensen, behoeften, talenten en motivaties. Bewoners moeten vanaf de start en gedurende het hele proces mee kunnen denken: van visie- en planvorming tot uitvoering, evaluatie en doorontwikkeling. Voor een goede betrokkenheid moet de input van bewoners snel worden omgezet in acties en mag niet van bewoners worden verwacht dat ze in een langdurig traject participeren. 
'Je moet ook niet verwachten dat je bewoners mee krijgt in een lang ontwikkel- en organisatietraject. Daar word je zelf ook heel ongelukkig van.' (programmagroepslid)

Wanneer bewoners verantwoordelijkheid wordt gegeven zal dat de samenwerking ten goede komen. Het is dan wel wenselijk dat de coördinerende rol door een professional wordt vervuld.

\section{Profileren van de aanpak}

Het onder de aandacht brengen van de aanpak is volgens de respondenten vooral belangrijk voor het creëren van bekendheid in de stad en toewijding bij de betrokken netwerkorganisaties. Een respondent gaf aan dat een goede informatieve website over Zwolle Gezonde Stad positief zou bijdragen aan het profileren van de aanpak. Gedurende de eerste drie jaar van de implementatie (2010-2013) waren er financiële middelen beschikbaar voor externe communicatie, waardoor een communicatiemedewerker tijd kon besteden aan het opstellen en uitvoeren van een communicatieplan. Die middelen zijn er niet meer, waardoor de externe communicatie is versoberd.

Bij het profileren van de aanpak kan worden gedacht aan het onder de aandacht brengen van succesverhalen rond Zwolle Gezonde Stad. Deze zorgen ervoor dat ook andere organisaties willen deelnemen aan de aanpak en het netwerk.

'Stel, SportService Zwolle organiseert iets moois voor jongeren of voor ouderen dat heel mooi en succesvol is, maar in de communicatie wordt het naar buiten gebracht dat het vanuit SportService Zwolle is en er wordt eigenlijk niet of nauwelijks een link gemaakt naar Zwolle Gezonde Stad. En dat maakt dat ik vind dat de beweging eigenlijk wel succesvol is, maar dat het niet duidelijk wordt naar buiten toe.' (programmagroepslid)

Volgens de respondenten vinden bewoners het leuk om deel te nemen aan een activiteit met professionals X van organisatie $\mathrm{Y}$, maar maakt het voor hen niet uit of de activiteit onderdeel uitmaakt van de aanpak of niet.

\section{Meebewegen met en gebruikmaken van mogelijkheden en kansen}

Volgens de respondenten is 'aansluiten bij dat wat er al is’ kenmerkend voor de aanpak. Bij Zwolle Gezonde Stad zie je dat op drie manieren:

1. De aanpak is een uitbreiding van een indertijd lopende aanpak die bestond uit een kleiner netwerk aan organisaties, met ongeveer dezelfde missie. Door voort te bouwen op dat bestaande netwerk kenden sommige professionals elkaar al, wat de start in 2010 vergemakkelijkte.
2. De aanpak sluit zo veel mogelijk aan bij de reguliere werkzaamheden, activiteiten en processen van de betrokken organisaties.

3. Zwolle Gezonde Stad probeert aan te sluiten bij nationale ontwikkelingen. Nationale aandacht voor een bepaald onderwerp, zoals de themacampagnes van JOGG voor het bevorderen van water drinken en de Gezonde School-aanpak, kan middelen, materialen en 'energie' opleveren voor lokale implementatie.

'De gezonde schoolaanpak, dat is iets wat landelijk al zes, zeven jaar gestimuleerd wordt en daar haak je op aan om te zorgen dat scholen "gezond" zijn en dat het niet een hapsnapproject is dat dan weer stopt. Als de geldkraan stopt bij scholen, stopt ook vaak dat specifieke programma. Dan vind ik het wel mooi dat wij de wind mee hebben en dat wij kunnen aansluiten op bestaande subsidieregelingen.' (programmagroepslid)

\section{Borgen van de aanpak in beleid en processen van organisaties}

In de eerste drie jaar van Zwolle Gezonde Stad (2010-2013) werd de aanpak gezien als een programma met een uitvoeringsprogramma en gefinancierde projecten. Na het overgangsjaar 2014, waarin de aandacht uitging naar borging van de aanpak, werd het gezien als een meer organische 'beweging', waarin verschillende organisaties aan een gemeenschappelijk doel werken. Het is een netwerk van organisaties waarin professionals gebruikmaken van elkaars expertises. Volgens de respondenten is de aanpak inmiddels geborgd in het beleid en de reguliere werkzaamheden van de betrokken organisaties.

'Eerder was het natuurlijk een programma dat ook heel erg agendazettend was. Heel erg bij partijen "gezondheid" tussen de oren moesten krijgen. $\mathrm{Nu}$ zie je dat het tussen de oren zit, maar kijken we waar zit de verbinding en hoe maken we gebruik van elkaars expertise?' (programmagroepslid)

Het risico van spreken over het borgen van de aanpak is dat de aandacht voor het thema afneemt. Om die reden is het volgens de respondenten belangrijk dat er blijvend een interne coördinator verantwoordelijk is voor het onder de aandacht brengen van het thema bij collega's.

\section{Doorlopend monitoren van proces en effect, en acties verbinden aan de bevindingen}

Alle respondenten geven aan dat het belangrijk is om de effecten en processen te monitoren en evalueren. Het aantonen van effecten draagt positief bij aan de betrokkenheid van de organisaties. Door het proces te evalueren kan de aanpak continu worden aangepast en kunnen discussies worden gevoerd over 'waar staan we nu' en 'hoe gaan we verder'. 
Dat het lectoraat De Gezonde Stad (nu Gezonde Samenleving) van Hogeschool Windesheim vanaf het begin betrokken is bij Zwolle Gezonde Stad draagt positief bij aan dit kernelement. De onderzoekers van het lectoraat zijn verantwoordelijk voor het monitoren en evalueren van de aanpak. Bovendien zijn via het lectoraat ook studenten van verschillende opleidingen bij het project betrokken, die in opdracht van de betrokken organisaties (verkennende) onderzoeksopdrachten uitvoeren.

\section{Beschouwing}

In dit onderzoek zijn negen kernelementen geïdentificeerd die volgens de betrokken professionals hebben bijgedragen aan het succes van Zwolle Gezonde Stad, een integrale aanpak gericht op het verkleinen van SEGV. De kernelementen gaan over samenwerking tussen diverse lokale organisaties, draagvlak op strategisch, tactisch en operationeel niveau, communicatie en coördinatie, samenwerking met private organisaties, samenwerking met bewoners, profilering van de aanpak, meebewegen met en gebruikmaken van kansen, borging van de aanpak en het continu monitoren en evalueren van effecten en processen, en leren van die uitkomsten. Van Koperen en collega's en het British National Institute for Health and Clinical Excellence (NICE) onderschrijven net als wij het belang van een brede en domeinoverstijgende groep van organisaties die bijdragen aan een gemeenschappelijk doel $[22,23]$. Anders dan wij beschrijft NICE niet expliciet de noodzaak van politiek-bestuurlijk draagvlak op strategisch niveau bij een complexe aanpak voor gezond gedrag. Bellow en collega's doen dat wel [24]. Volgens deze auteurs is intersectorale samenwerking op bestuurlijk niveau met een gemeenschappelijk beleidsdoel nodig, om uitvoerende organisaties uit verschillende domeinen erbij te betrekken. Leiderschap en coördinatie om bruggen te slaan tussen de verschillende domeinen en niveaus zijn daarbij essentieel. Ook dit sluit aan bij onze bevinding dat communicatie en coördinatie kernelementen vormen. Ook is het voor de duurzaamheid van wijkgerichte benaderingen belangrijk dat er een politiek draagvlak is [25]. Corbin en collega's bevestigen in hun literatuurreview dat het belangrijk is dat een brede groep organisaties een gezamenlijke missie hebben [26]. Ook stellen ze dat evaluatie van de samenwerking noodzakelijk is met het oog op een continue verbetering van de aanpak, wat strookt met onze bevinding over doorlopend evalueren en monitoren. Onze conclusie over het belang van samenwerking met bewoners, zodat de aanpak wordt afgestemd op hun wensen, behoeften, talenten en motivaties, stemt overeen met de bevindingen van recent onderzoek naar community engagement [27]. O’Mara-Eves en collega's concluderen in een meta-analyse zelfs dat betrokkenheid van bewoners een positief effect heeft op de gezondheid van lage SEP-populaties [28].
In 2010 is de Zwolle Gezonde Stad-aanpak gestart met een aantal verwachte sleutelelementen, die zijn afgeleid van de EPODE-benadering in Frankrijk. Dit heeft geleid tot een logisch model dat als leidraad voor de aanpak fungeerde. De respondenten in dit onderzoek bevestigen de waarde van de meeste elementen. Opvallend is dat dit niet het geval is voor 'verbinding van preventie en zorg'. De aanpak heeft ingezet op het versterken van de verbinding tussen preventie en zorg op projectbasis. Toch zien de respondenten dit niet als een kernelement omdat hier volgens hen te weinig op is ingezet. Ook blijkt uit dit onderzoek dat samenwerking met bewoners een belangrijk kernelement is, wat onvoldoende is opgenomen in het huidige logisch model.

\section{Methodologische reflectie}

Door een gevarieerde groep professionals te interviewen over een implementatieperiode van acht jaar, konden we de kernelementen aanwijzen. Toch kent dit onderzoek ook beperkingen. Het onderzoeksontwerp was retrospectief van opzet, wat kan hebben geleid tot minder gedetailleerde ervaringen omdat het begin van de aanpak ruim acht jaar geleden was. Omdat de aanpak succesvol is gebleken, kijken respondenten misschien vooral terug op de positieve kanten van de implementatie en bagatelliseren ze de negatieve kanten. Om dit effect te ondervangen heeft de interviewer (LW) vooraf het verslag van de gesprekken met (een selectie van) dezelfde professionals uit 2013 gelezen. Daardoor kon de interviewer de respondenten helpen met het herinneren van de details over de eerste drie jaar.

\section{Implicaties voor praktijk en onderzoek}

Professionals die betrokken zijn bij de aanpak Zwolle Gezonde Stad kunnen van het overzicht van kernelementen leren omdat dit richting geeft aan eventuele verbetering van Zwolle Gezonde Stad. Dit zou in samenwerking met bewoners moeten worden gedaan om de aanpak goed aan te laten sluiten bij hun wensen, behoeften, talenten en motivatie. Het is belangrijk om bewoners vanaf de start en gedurende het hele proces mee te laten denken: van visie- en planvorming tot uitvoering, evaluatie en doorontwikkeling. Op basis van vervolgonderzoek in Zwolle zou een aangepast logisch model kunnen worden ontwikkeld. Inzichten opgedaan in dit onderzoek geven daar reden toe. Bovendien kunnen de resultaten andere lokale integrale benaderingen inspireren.

Zwolle Gezonde Stad richt zich op meerdere sectoren (bijvoorbeeld volksgezondheid, welzijn, ruimtelijke ordening, verkeer en vervoer) en meerdere niveaus (persoonlijk, organisatie, wijk en beleid). Een dergelijke benadering is lange tijd de standaard geweest voor het aanpakken van complexe problemen, zoals SEGV. Recente literatuur besteedt echter in 
toenemende mate aandacht aan de relaties tussen die verschillende niveaus in een systeembenadering [29-31]. De complexiteit van zo'n benadering ligt niet alleen in de relaties tussen de verschillende niveaus, maar ook in de manier waarop die relaties in een bepaalde context werken. Zo moet er volgens Vamos en collega's binnen zo'n aanpak niet alleen ingezet worden op individuele gedragsverandering, maar ook op het veranderen van de fysieke leefomgeving, het verbeteren van de ondersteuning door professionals en het ondersteunen van kinderen en families om gezond gedrag te stimuleren [31]. Deze factoren hangen onderling samen - gezond gedrag wordt bijvoorbeeld eerder vertoond in een fysieke leefomgeving die daartoe uitnodigt. Om die reden is het wenselijk om deze aanpak op meerdere niveaus binnen dit complexe systeem in te zetten. Attwood en collega's stellen dat we deze benaderingen niet als one size fits all moeten beschouwen, maar de vraagstukken binnen hun bredere context moeten zien [32]. Vragen als 'hoe werkt het?' en 'in welke context werkt het?' zijn net zo belangrijk als de vraag 'wat werkt?'. Voor de evaluatie van een aanpak impliceert dit dat het niet alleen belangrijk is om te beschrijven wat de kernelementen van een aanpak zijn, maar ook welke dynamische processen de impact van de kernelementen kunnen versterken of belemmeren. Daarom zou vervolgonderzoek zich moeten richten op het vaststellen van de mechanismen die verband houden met de kernelementen en het beschrijven van de context waarin deze mechanismen werken.

Open Access This article is licensed under a Creative Commons Attribution 4.0 International License, which permits use, sharing, adaptation, distribution and reproduction in any medium or format, as long as you give appropriate credit to the original author(s) and the source, provide a link to the Creative Commons licence, and indicate if changes were made. The images or other third party material in this article are included in the article's Creative Commons licence, unless indicated otherwise in a credit line to the material. If material is not included in the article's Creative Commons licence and your intended use is not permitted by statutory regulation or exceeds the permitted use, you will need to obtain permission directly from the copyright holder. To view a copy of this licence, visit http://creativecommons.org/licenses/by/4.0/.

\section{Literatuur}

1. Pampel FC, Krueger PM, Denney JT. Socioeconomic disparities in health behaviors. Annu Rev Sociol. 2010;36:349-70.

2. Mackenbach JP, Stirbu I. Roskam A-JR, et al. Socioeconomic inequealities in health in 22 European countries. N Engl J Med. 2008;358(23):2468-81.

3. Roskam A-JR, Kunst AE, Oyen $\mathrm{H}$ van, et al. Comparative appraisal of educational inequalities in overweight and obesity among adults in 19 European countries. Int J Epidemiol. 2009;39(2):392-404.

4. Giskes K, Avendano M, Brug J, et al. A systematic review of studies on socioeconomic inequalities in dietary intakes associated with weight gain and overweight/obesity conducted among European adults. Obes Rev. 2009;11(6):413-29.
5. Schneiderman N, Ironson G, Siegel SD. Stress and health: psychological, behavioral, and biological determinants. Ann Rev Clin Psychol. 2005;1:607-28.

6. Major B, Mendes WB, Dovidio JF. Intergroup relations and health disparities: a social psychological perspective. Health Psychol. 2013;32(5):514.

7. Rikard R, Thompson MS, McKinney J, et al. Examining health literacy disparities in the United States: a third look at the National Assessment of Adult Literacy (NAAL). BMC Public Health. 2016;16(1):975.

8. Ball K, Timperio A, Salmon J, et al. Personal, social and environmental determinants of educational inequalities in walking: a multilevel study. JEpidemiolCommunity Health. 2007;61(2):108-14.

9. Lindström M, Hanson BS, Östergren PO. Socioeconomic differences in leisure-time physical activity: the role of social participation and social capital in shaping health related behaviour. Soc Scie Med. 2001;52(3):441-51.

10. Lovasi GS, Hutson MA, Guerra M, et al. Built environments and obesity in disadvantaged populations. Epidemiol Rev. 2009;31(1):7-20.

11. Ball K. Traversing myths and mountains: addressing socioeconomic inequities in the promotion of nutrition and physical activity behaviours. Int J Behav Nutr Phys Act. 2015;12(1):142.

12. Macdonald L, Cummins S, Macintyre S. Neighbourhood fast food environment and area deprivation - substitution or concentration? Appetite. 2007;49(1):251-4.

13. Lake AA. Neighbourhood food environments: food choice, foodscapes and planning for health. Proc Nutr Soc. 2018;77(3):239-46.

14. Aarts M-J, Wendel-VosW, Oers HAMvan, etal. Environmental determinants of outdoor play in children: a large-scale cross-sectional study. Am J Prev Med. 2010;39(3):212-9.

15. Bambra C, Gibson M, Sowden A, et al. Tackling the wider social determinants of health and health inequalities: evidence from systematic reviews. JEpidemiol Community Health. 2010;64(4):284-91.

16. Hillier-Brown FC, Bambra CL, Cairns J-M, et al. A systematic review of the effectiveness of individual, community and societal level interventions at reducing socioeconomic inequalities in obesity amongst children. BMC Publ Heal. 2014;14(1):834.

17. Poos MJJC, Nusselder WJ, Bruggink JW. Gezonde levensverwachting: zijn er verschillen naar sociaaleconomische status? Volksgezondheid Toekomst Verkenning, Nationaal Kompas Volksgezondheid. Bilthoven: RIVM;2014.

18. Visscher TL, Güner Ö, Schwartz D, et al. Evaluatie programma Zwolle Gezonde Stad 2010-2013. Zwolle: ChristelijkeHogechoolWindesheim; 2014.

19. Collard D, Slot-Heijs J, Dellas V, et al. Monitor Jongeren op Gezond Gewicht 2018. Utrecht: Mulier Instituut; 2019.

20. Borys JM, Richard P, Ruault du Plessis H, et al. Tackling health inequities and reducing obesity prevalence: the EPODE community-based approach. Ann Nutr Metab. 2016;68(2):35-8.

21. Stad ZG. Visiedocument verbreding Zwolle Gezonde Stad. www.zwolle.nl/sites/default/files/visiedocument zwolle_gezonde_stad_2014-2016.pdf. Geraadpleegd op: 8 apr 2020.

22. Koperen TM van, Wietmarschen $M$ van, Seidell J, et al. Amsterdamse Aanpak Gezond Gewicht: kansrijk? Een zoektocht naar werkzame elementen. Utrecht: NJI;2018.

23. National Clinical Guideline Centre (UK).. Obesity: identification, assessment and management of overweight and obesity in children, young people and adults. band 2014. 
London: National Institute for Health and Care Excellence (UK);2016.

24. Bellow B, Cavill N, Allender S, et al. Strategic principles and capacity building for a whole-of-systems approaches to physical activity. Sheffield: Sheffield Halam University; 2020.

25. Ceptureanu S, Ceptureanu E, Lucian C, et al. Community based programs sustainability. A multidimensional analysis of sustainability factors. Sustainability. 2018;10(3):870.

26. Corbin JH, Jones J, Barry MM. What makes intersectoral partnerships for health promotion work? A review of the international literature. Health Promot Int. 2018;33(1):4-26.

27. Weger $\mathrm{E}$ de, Vooren $\mathrm{N}$ van, Luijkx KG, et al. Achieving successful community engagement: a rapid realist review. BMCHealth Serv Res. 2018;18(1):285.

28. O'Mara-Eves A, Brunton GOS, et al. The effectiveness of community engagement in public health interventions for disadvantaged groups: a meta-analysis. BMC Public Health. 2015;15(1):129.

29. Garside R, Pearson M, Hunt H, et al. Preventing obesity using a 'whole system' approach at local and community level: PDG1 Identifying the key elements and interactions of a whole system approach. Report for NICECentre for Public Health Excellence. 2010.

30. Lobstein T, Jackson-Leach R, Moodie ML, et al. Child and adolescent obesity: part of a bigger picture. Lancet. 2015;385(9986):2510-20.

31. Vamos EP, Lewis E, Junghans C, et al. Community-based pilot intervention to tackle childhood obesity: a wholesystem approach. Public Health. 2016;140:109-18.

32. Attwood M, Pritchard S, Pedler M, et al. Leading change: a guide to whole systems working. Bristol: Policy Press; 2003. 